\title{
Does the Polymorphism in the Length of the Polyalanine Tract of FOXE1 Gene Influence the Risk of Thyroid Dysgenesis Occurrence?
}

\author{
Clebson Pantoja Pimentel, ${ }^{1}$ Erik Artur Cortinhas-Alves, ${ }^{1,2}$ \\ Edivaldo Herculano Correa de Oliveira, ${ }^{3,4}$ and Luiz Carlos Santana-da-Silva ${ }^{1}$ \\ ${ }^{1}$ Laboratório de Erros Inatos do Metabolismo, Instituto de Ciências Fisiológicas, Universidade Federal do Pará, Belém, PA, Brazil \\ ${ }^{2}$ Departamento de Morfologia e Ciências Fisiológicas, Universidade do Estado do Pará, Belém, PA, Brazil \\ ${ }^{3}$ Laboratório de Cultura de Tecidos e Citogenética, SAMAM, Instituto Evandro Chagas, Ananindeua, PA, Brazil \\ ${ }^{4}$ Instituto de Ciências Exatas e Naturais, Universidade Federal do Pará, Belém, PA, Brazil
}

Correspondence should be addressed to Clebson Pantoja Pimentel; clebsonpp@yahoo.com.br

Received 7 September 2017; Accepted 6 November 2017; Published 28 November 2017

Academic Editor: Marian Ludgate

Copyright @ 2017 Clebson Pantoja Pimentel et al. This is an open access article distributed under the Creative Commons Attribution License, which permits unrestricted use, distribution, and reproduction in any medium, provided the original work is properly cited.

\begin{abstract}
Background. Recent data have suggested that polymorphisms in the length of the polyalanine tract (polyA) of FOXE1 gene may act as a susceptibility factor for thyroid dysgenesis. The main purpose of this study was to investigate the influence of polyA of FOXE1 gene on the risk of thyroid dysgenesis. Method. A case-control study was conducted in a sample of 90 Brazilian patients with thyroid dysgenesis and 131 controls without family history of thyroid disease. Genomic DNA was isolated from peripheral blood samples and the genotype of each individual was determined by automated sequencing. Results. More than 90\% of genotypes found in the group of patients with thyroid dysgenesis and in controls subjects were represented by sizes 14 and 16 polymorphisms in the following combinations: 14/14, 14/16, and 16/16. Genotypes 14/16 and 16/16 were more frequent in the control group, while genotype 14/14 was more frequent in the group of patients with thyroid dysgenesis. There was no difference between agenesis group and control group. Genotype 14/14 when compared to genotypes 14/16 and 16/16A showed an association with thyroid dysgenesis. Conclusion. PolyA of FOXE1 gene alters the risk of thyroid dysgenesis, which may explain in part the etiology of this disease.
\end{abstract}

\section{Introduction}

Congenital hypothyroidism $(\mathrm{CH})$ is the most common congenital endocrine disease in childhood and is also a preventable cause of mental deficiency, affecting about one in 3,000-4,000 live births [1,2]. Thyroid development defects represent $85 \%$ of $\mathrm{CH}$ cases and are collectively referred to as thyroid dysgenesis (TD), a term that includes agenesis (35-40\%), ectopy (30-45\%), and hypoplasia (5\%) [3, 4]. However, the etiology of TD is still unclear but can be explained on a small scale by genetic mutations in 4 transcription factors (FOXE1 [5], NKX2.1 [6], PAX8 [7, 8], and NKX2.5 [9]) and at the thyrotrophin receptor [10], which are genes important in the development and normal function of the thyroid gland [11-13].
Among TD-related genes, FOXE1 gene plays an important role in the migration of precursor cells from thyroid follicles, in addition to being a factor that regulates the transcription of target genes such as thyroglobulin and thyroperoxidase [14]. FOXE1 gene (also called TTF-2 or FKHL15) is located on chromosome 9q22.33 and contains a single exon distributed along $3,461 \mathrm{bp}$. This gene encodes a $42 \mathrm{kDa}$ protein that contains a forkhead domain and a polyalanine (polyA) tract of variable length (11 to 22 alanine residues) [5, 15, 16]. Polymorphism in the length of the polyA tract in different genes has been associated with different diseases [17, 18]. Studies show that polymorphism in the length of the polyA tract of FOXE1 gene (rs71369530) is associated with thyroid disorders [19-21]. 
The mechanism by which variants of the polyA tract act in the $\mathrm{CH}$ development have been extensively studied in different populations and results from these studies sometimes differ regarding the influence of the polyA tract on the TD development [18-23], so it is important to know the distribution of mutations and allelic and genotypic frequencies of polymorphisms present in the gene involved in the embryonic development of the thyroid in different populations. Thus, the aim of this work was to investigate variations in the length of the polyA tract of FOXE1 gene in a group of Brazilian patients with $\mathrm{CH}$ in order to better elucidate the potential role of this tract in the genetic susceptibility to TD.

\section{Subjects and Methods}

2.1. Sample. Initially, 120 patients with TD were selected through the National Neonatal Screening Program database held at the State University of Pará. All patients came from northern Brazil. To be included in the study, patients should meet the following inclusion criteria: (i) diagnosis of $\mathrm{CH}$ according to the biochemical and clinical criteria of the National Neonatal Screening Program (neonatal TSH level less than $10 \mathrm{mUI} / \mathrm{L} 48 \mathrm{~h}$ after birth); (ii) etiological diagnosis of TD type performed through thyroid scintigraphy; (iii) patients could not present a family relationship with each other and (iv) stable use of medication (Levothyroxine). Patients who did not present a conclusive examination of TD type were excluded.

After observing the inclusion and exclusion criteria, 90 patients (34 males and 56 females) were divided according to TD type. Among patients, 47 (51\%) presented ectopy, 33 (38\%) agenesis, and 10 (11\%) hypoplasia of the thyroid gland. The control group was composed of 131 normal individuals (50 male and 81 female) with no history of $\mathrm{CH}$ in the family, who were selected to conduct the case-control association study (Figure 1).

This work is in accordance with the ethical principles that govern human research. The present study was approved by the Ethics Research Committee of the Santa Casa de Misericórdia Foundation Hospital of the State of Pará (2005/0811).

2.2. Genotyping. Genomic DNA was isolated from $300 \mu \mathrm{L}$ of peripheral blood samples using Invisible Spin Blood Mini Kit (Invitrogen of Brazil Ltda., São Paulo, SP, Brazil). The polyA tract of FOXE1 gene was amplified by polymerase chain reaction (PCR) in final volume of $25 \mu \mathrm{L}$, using primes described by Carré et al. (2007) [24]. The PCR mix contained 1x PCR buffer (Invitrogen), $0.2 \mathrm{mM}$ of each dNTP, $1.5 \mathrm{mM} \mathrm{MgCl} 2,2 \mathrm{pmol}$ of each primer, and $0.1 \mathrm{U}$ of $\mathrm{GC}$ rich Taq polymerase (Roche Diagnostics). After an initial denaturation step at $98^{\circ} \mathrm{C}$ for $30 \mathrm{~s}, 35$ cycles were carried out, each consisting of $1 \mathrm{~min}$ at $98^{\circ} \mathrm{C}$, primer annealing at $55^{\circ} \mathrm{C}$ for $30 \mathrm{~s}$, and primer extension of $60 \mathrm{~s}$ at $72^{\circ} \mathrm{C}$, followed by a final extension of $5 \mathrm{~min}$ at $72^{\circ} \mathrm{C}$. Amplification was carried out on a gradient thermal cycler (MJ96 +/MJ96G, Biosystems). All PCR products were checked for specificity

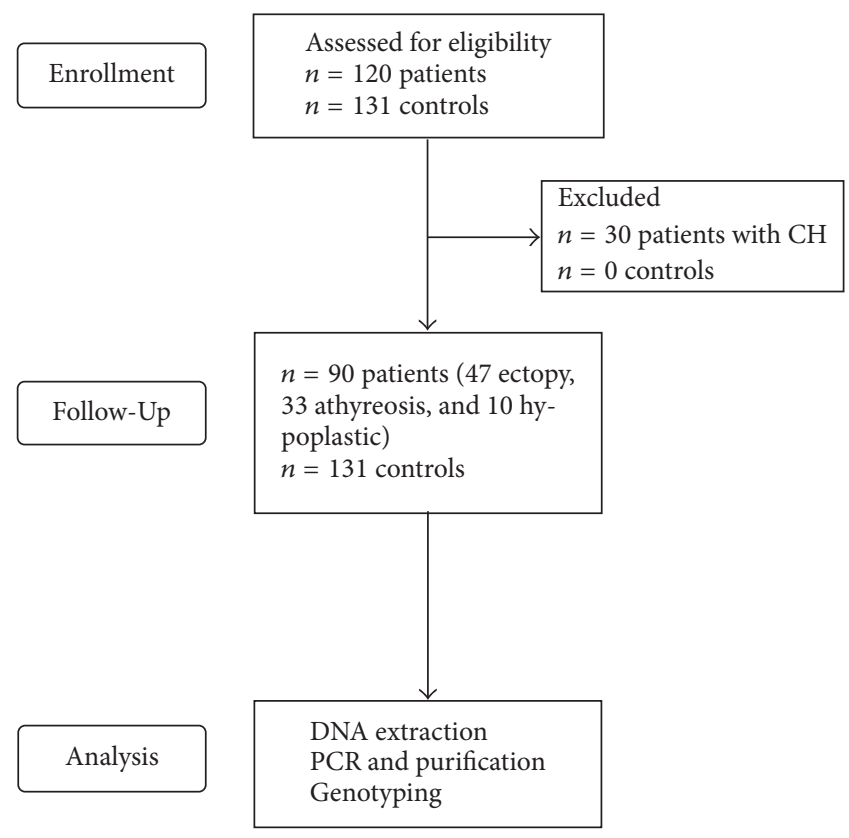

FIGURE 1: Flowchart diagram of this study.

on a $1.5 \%$ agarose gel. Amplicons were purified using PureLink $^{\mathrm{TM}}$ PCR Purification kit (Invitrogen of Brazil Ltda., São Paulo, SP, Brazil). The genotypes of the sample studied were determined by direct sequencing using Big Dye Terminator Cycle Sequencing Standart Version 3.1 kit. PCR products were analyzed on an Applied Biosystems sequencer, model ABI 3130 (Applied Biosystems of Brazil Ltda., São Paulo, SP, Brazil).

2.3. Statistical Analysis. SPSS software (version 20) was used in data analysis. The $X^{2}$ test was used to compare the allelic and genotype frequency of the polyA tract between patients with TD and individuals in the control group and with frequencies found in other studies. The odds ratio (OR) test with a 95\% confidence interval was used to evaluate the strength of association between genotypes found and the etiology of TD. The frequencies of genotypes in the length of the polyA tract of FOXE1 gene are described in the form of absolute and percentage values in Table 1.

\section{Results}

The sequencing analysis of the FOXE1 gene identified 6 polymorphisms in the length of the polyA tract of FOXE1 gene that were found in 9 different combinations in patients and controls (Table 1). The gender ratio in both groups did not show significant difference $\left(X^{2}=0.003, p=0.934\right)$.

More than $90 \%$ of the genotypes found in the TD group (ectopy, agenesis, and hypoplasia) and in the control subjects were represented by sizes 14 and 16 polymorphisms in the following combinations: 14/14, 14/16, and 16/16. Genotype $14 / 14$ was used as a reference for odds ratio calculations for all groups, since this genotype was the most frequent in both TD (ectopy-72.3\%, agenesis - $66.7 \%$ and hypoplasia-70\%) 
TABLE 1: Genotypes of DT patients and control subjects according to the polymorphism in the length of the polyA tract of FOXE1 gene.

\begin{tabular}{|c|c|c|c|c|c|}
\hline \multirow{2}{*}{ Genotypes } & \multicolumn{4}{|c|}{ Patients } & \multirow{2}{*}{$\begin{array}{l}\text { Controls } \\
n(\%)\end{array}$} \\
\hline & $\begin{array}{c}\text { Ectopy } \\
n(\%)\end{array}$ & $\begin{array}{c}\text { Agenesis } \\
n(\%)\end{array}$ & $\begin{array}{c}\text { Hypoplasia } \\
n(\%)\end{array}$ & $\begin{array}{l}\text { Total } \\
n(\%)\end{array}$ & \\
\hline $11 / 14$ & $0(0)$ & $0(0)$ & $0(0)$ & $0(0)$ & $0(0)$ \\
\hline $12 / 14$ & $1(2.1)$ & $0(0)$ & $0(0)$ & $1(1.1)$ & $2(1.5)$ \\
\hline $12 / 16$ & $0(0)$ & $1(3)$ & $0(0)$ & $1(1.1)$ & $2(1.5)$ \\
\hline $14 / 14$ & $34(72.3)$ & $22(66.7)$ & $7(70)$ & $63(70)$ & $53(40.5)$ \\
\hline $14 / 16$ & $10(21.3)$ & $8(24.2)$ & $2(20)$ & $20(22.2)$ & 49 (37.4) \\
\hline $14 / 17$ & $0(0)$ & $1(3)$ & $0(0)$ & $1(1.1)$ & $1(0.8)$ \\
\hline $14 / 19$ & $0(0)$ & $0(0)$ & $0(0)$ & $0(0)$ & $1(0.8)$ \\
\hline $16 / 16$ & $2(4.3)$ & $1(3)$ & $1(10)$ & $4(4.4)$ & $22(16.8)$ \\
\hline $16 / 17$ & $0(0)$ & $0(0)$ & $0(0)$ & $0(0)$ & $1(0.8)$ \\
\hline Total & 47 (100) & 33 (100) & $10(100)$ & $90(100)$ & $131(100)$ \\
\hline
\end{tabular}

TABLE 2: Odds ratio of genotypes to the polymorphism in the length of the polyA tract of FOXE1 gene in all DT patients and control subjects.

\begin{tabular}{|c|c|c|c|c|c|}
\hline Genotypes & $\begin{array}{c}\text { Patients } \\
n(\%)\end{array}$ & $\begin{array}{c}\text { Controls } \\
n(\%)\end{array}$ & OR & $95 \%$ CI & $p$ value \\
\hline $14 / 14$ & $63(70)$ & $53(40.5)$ & 1 & - & - \\
\hline $14 / 16$ & $20(22.2)$ & 49 (37.4) & 0.34 & $0.18-0.64$ & $<0.001$ \\
\hline $16 / 16$ & $4(4.4)$ & $22(16.8)$ & 0.15 & $0.05-0.47$ & $<0.001$ \\
\hline $14 / 16$ e $16 / 16$ & $24(26.7)$ & $71(54.2)$ & 0.28 & $0.16-0.51$ & $<0.001$ \\
\hline Others & $3(3.3)$ & $7(5.3)$ & - & - & - \\
\hline Total & $90(100)$ & $131(100)$ & - & - & - \\
\hline
\end{tabular}

TABLE 3: Odds ratio of genotypes to the polymorphism in the length of the polyA tract of FOXE1 gene in DT subgroup (ectopy, agenesis, and hypoplasia) and controls subjects.

\begin{tabular}{|c|c|c|c|c|c|c|}
\hline \multirow{2}{*}{ Groups $(n)$} & \multicolumn{2}{|c|}{ Genotypes } & \multirow{2}{*}{ Others } & \multirow{2}{*}{ OR } & \multirow{2}{*}{$95 \%$ CI } & \multirow{2}{*}{$p$ value } \\
\hline & $14 / 14$ & $14 / 16+16 / 16$ & & & & \\
\hline Ectopy (47) & $34(72 \%)$ & $12(26 \%)$ & $1(2 \%)$ & 0.26 & $0.12-0.56$ & $<0.001$ \\
\hline Agenesis (33) & $22(67 \%)$ & $9(27 \%)$ & $2(6 \%)$ & 0.31 & $0.13-0.72$ & 0.005 \\
\hline Hypoplasia (10) & $7(70 \%)$ & $3(30 \%)$ & $0(0 \%)$ & 0.32 & $0.08-1.3$ & 0.095 \\
\hline Controls (131) & $53(41 \%)$ & $71(54 \%)$ & $7(5 \%)$ & - & - & - \\
\hline
\end{tabular}

and control groups $(40.5 \%)$. The $X^{2}$ test showed a significant difference $(p<0.0001)$ in the proportions of genotypes $14 / 14,14 / 16$, and $16 / 16$ when comparing patients with TD and control subjects (Table 2 ). When compared to genotypes 14/16 and $16 / 16$, genotype $14 / 14$ showed an association with TD (OR $=3.52,95 \% \mathrm{CI}=1.95-6.34, p<0.001)$.

When the proportions of genotypes were analyzed according to the subgroups of ectopy and agenesis, it was possible to observe that genotypes $14 / 16+16 / 16$ were more frequent in the control group $(p<0.001$ and $p=0.005)$, while genotype $14 / 14$ was more frequent in the TD group $(p<0.001)$. There was no difference between hypoplasia group and control group ( $p=0.095)$ (Table 3$)$.

Allele 14 was the most frequent in our sample and in all studies previously published (Hishinuma et al., 2001, Tonacchera et al., 2004; Watkins et al., 2006; Santarpia et al., 2007). However, the allele distribution found in this study was significantly different from the frequencies found in the other studies (Table 4).

\section{Discussion}

The main finding of the present study evidenced that polymorphism in the length of the polyA tract of FOXE1 gene is associated with genetic susceptibility of TD. Our results indicate that the presence of allele 16 in the polyA tract may be a protective factor against TD compared to genotype 14/14 $(\mathrm{OR}=0.28 ; p<0.001)$. In addition, it was observed that the presence of allele 16 in the polyA tract decreased the risk for TD, since, in the 16/16 genotype, OR was $0.15(p<0.001)$ (Table 2).

Allele 16 has already been described as an important factor to reduce the risk of ectopy [24]. In the sample analyzed in this study, polymorphisms in the length of the polyA tract 


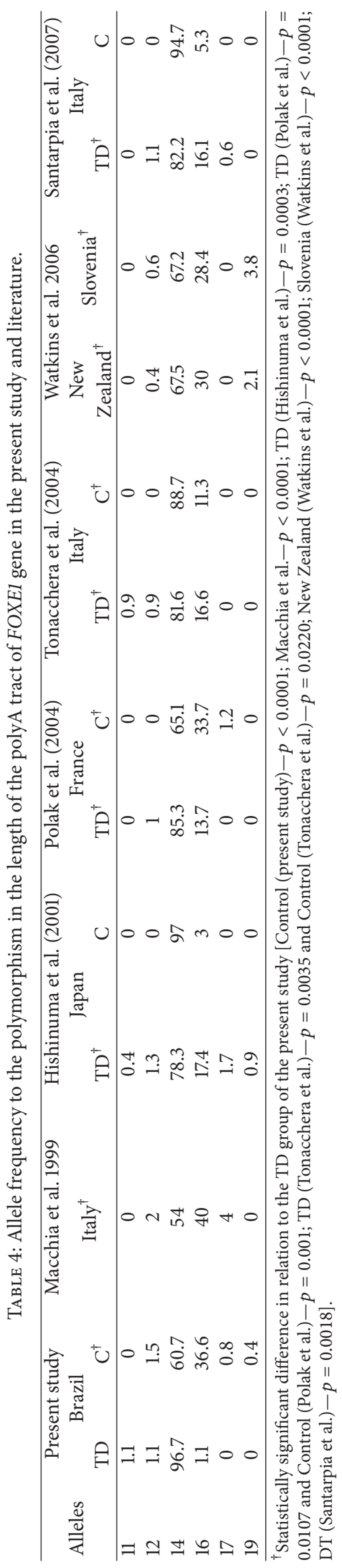


were associated with the risk of occurrence of TD in the group of patients with ectopy and dysgenesis. Thus, TD is associated with the most common variable (allele 14), as it was possible to evaluate through genotype $14 / 14$, which when compared to genotypes 14/16 and 16/16 shows an association with TD (OR $=3.52 ; \%=1.95-6.34, p<0.001$ ).

Polymorphism of the polyA tract of other transcription factors has already been associated with more severe clinical findings in other diseases and even to increased morbidity $[17,25]$. It is known that the FOXE1 gene plays an important role in the migration and proliferation of embryonic cells that give rise to the thyroid gland, since the animal model data indicate that mice with knockout of this gene exhibit cleft palate and thyroid malformation (agenesis and ectopy) $[7,26]$. Moreover, clinical studies on humans have shown that changes in the structure of FOXE1 gene (caused by mutations or alterations in the size of the polyA tract) are linked to TD, causing thyroid agenesis [5, 27-29].

The difference in allele frequencies of polymorphisms of the polyA tract can be explained by the different ethnic groups analyzed, especially in our sample, which was composed of population characterized by a high degree of miscegenation between Native Americans, African Americans, and Europeans, a result of the standard of the Brazilian territory colonization [30].

The effects of the polyA tract on the cellular dynamics and the transcription factors are still unclear, because studies have shown conflicting results about the FOXE1 gene with different length of the polyA tract $[24,25,31-33]$. Due to the complexity of thyroid development, it is reasonable to assume that other genes and proteins may have influence on the expression of the FOXE1 gene and its polymorphic variants. However, further studies are necessary to determine it experimentally.

The authors of this work believe that the genetic study of other signaling pathways involved with thyroid formation is important because the morphogenesis of this gland is controlled by a program of gene expression that is ultimately regulated by other transcription factors (TTF1, HHEX, NKX2.5, and $P A X 8$ ), which are organized into a network of genes that, in general, play a role in the proliferation, survival, and migration of thyroid precursor cells [26, 34]. In addition, new studies should be carried out with larger cohorts in order to better understand transmission imbalances, giving greater support to evidence obtained from case-control studies. In conclusion, the most frequent genotypes found were 14/14, $14 / 16$, and $16 / 16$, showing a variation among the studied samples. The variation in the length of the polyA tract of FOXE1 gene was associated with genetic susceptibility of TD. Allele 16 in the polyA tract may be a protective factor compared to genotype 14/14, decreasing the risk of TD. In addition, when compared to genotypes 14/16 and 16/16 polyA, genotype 14/14 was associated with increased risk of TD.

\section{Conflicts of Interest}

The authors report no conflicts of interest.

\section{Acknowledgments}

The authors would like to thank the patients and their parents for their participation in their study, as well as the funding agencies that supported this work: Fundação de Amparo à Pesquisa do Estado do Pará (FAPESPA, Grant no. 236/2009); Capacitação e Aperfeiçoamento de Pessoal de Ensino Superior (CAPES), Instituto Nacional de Genética Médica Populacional (Edital de Genética Clínica/CNPq, Grant no. 402050/2010-0); and Conselho Nacional de Desenvolvimento Científico e Tecnológico (CNPq, Grant no. 573993/2008-4).

\section{References}

[1] G. Van Vliet and J. Deladoëy, "Diagnosis, treatment and outcome of congenital hypothyroidism," Endocrine Development, vol. 26, pp. 50-59, 2014.

[2] A. J. Wassner and R. S. Brown, "Congenital hypothyroidism: Recent advances," Current Opinion in Endocrinology, Diabetes and Obesity, vol. 22, no. 5, pp. 407-412, 2015.

[3] R. Abu-Khudir, S. Larrivée-Vanier, J. D. Wasserman, and J. Deladoëy, "Disorders of thyroid morphogenesis," Best Practice \& Research: Clinical Endocrinology, vol. 31, no. 2, pp. 143-159, 2017.

[4] M. Nilsson and H. Fagman, "Development of the thyroid gland," Development, vol. 144, no. 12, pp. 2123-2140, 2017.

[5] R. J. Clifton-Bligh, J. M. Wentworth, P. Heinz et al., "Mutation of the gene encoding human TTF-2 associated with thyroid agenesis, cleft palate and choanal atresia," Nature Genetics, vol. 19, no. 4, pp. 399-401, 1998.

[6] K. Devriendt, C. Vanhole, G. Matthijs, and F. De Zegher, "Deletion of thyroid transcription factor-1 gene in an infant with neonatal thyroid dysfunction and respiratory failure [5]," The New England Journal of Medicine, vol. 338, no. 18, pp. 1317-1318, 1998.

[7] A. Mansouri, K. Chowdhury, and P. Gruss, "Follicular cells of the thyroid gland require Pax8 gene function," Nature Genetics, vol. 19, no. 1, pp. 87-90, 1998.

[8] C. Vilain, C. Rydlewski, L. Duprez et al., "Autosomal dominant transmission of congenital thyroid hypoplasia due to loss-offunction mutation of PAX8," The Journal of Clinical Endocrinology \& Metabolism, vol. 86, pp. 234-238, 2001.

[9] M. Dentice, V. Cordeddu, A. Rosica et al., "Missense mutation in the transcription factor NKX2-5: A novel molecular event in the pathogenesis of thyroid dysgenesis," The Journal of Clinical Endocrinology \& Metabolism, vol. 91, no. 4, pp. 1428-1433, 2006.

[10] N. De Roux, M. Misrahi, R. Brauner et al., "Four families with loss of function mutations of the thyrotropin receptor," The Journal of Clinical Endocrinology \& Metabolism, vol. 81, no. 12, pp. 4229-4235, 1996.

[11] M. De Felice, C. Ovitt, and E. Biffali, "A mouse model for hereditary thyroid dysgenesis and cleft palate," Nature Genetics, vol. 19, no. 4, pp. 395-398, 1998.

[12] M. De Felice and R. Di Lauro, "Thyroid development and its disorders: Genetics and molecular mechanisms," Endocrine Reviews, vol. 25, no. 5, pp. 722-746, 2004.

[13] S. S. Trueba, J. Augé, G. Mattei et al., "PAX8, TITF1, and FOXE1 gene expression patterns during human development: New insights into human thyroid development and thyroid dysgenesis-associated malformations," The Journal of Clinical Endocrinology \& Metabolism, vol. 90, no. 1, pp. 455-462, 2005. 
[14] M. Castanet and M. Polak, "Spectrum of human Foxel/TTF-2 mutations," Hormone Research in Paediatrics, vol. 73, no. 6, pp. 423-429, 2010.

[15] B. P. Chadwick, F. Obermayr, and A.-M. Frischauf, "FKHL15, a new human member of the forkhead gene family located on chromosome 9q22," Genomics, vol. 41, no. 3, pp. 390-396, 1997.

[16] M. Zannini, V. Avantaggiato, E. Biffali et al., "Lauro, TTF-2, a new forkhead protein, shows a temporal expression in the developing thyroid which is consistent with a role in controlling the onset of the differentiation," The EMBO Journal, vol. 16, pp. 3185-3197, 1997.

[17] J. Amiel, B. Laudier, T. Attié-Bitach et al., "Polyalanine expansion and frameshift mutations of the paired-like homeobox gene PHOX2B in congenital central hypoventilation syndrome," Nature Genetics, vol. 33, no. 4, pp. 459-461, 2003.

[18] W. J. Watkins, S. E. Harris, M. J. Craven et al., "An investigation into FOXE1 polyalanine tract length in premature ovarian failure," Molecular Human Reproduction, vol. 12, no. 3, pp. 145149, 2006.

[19] P. E. Macchia, M.-G. Mattei, P. Lapi, G. Fenzi, and R. Di Lauro, "Cloning, chromosomal localization and identification of polymorphisms in the human thyroid transcription factor 2 gene (TITF2)," Biochimie, vol. 81, no. 5, pp. 433-440, 1999.

[20] A. Hishinuma, Y. Ohyama, T. Kuribayashi et al., "Polymorphism of the polyalanine tract of thyroid transcription factor-2 gene in patients with thyroid dysgenesis," European Journal of Endocrinology, vol. 145, no. 4, pp. 385-389, 2001.

[21] M. Tonacchera, M. Banco, P. Lapi et al., "Genetic analysis of TTF-2 gene in children with congenital hypothyroidism and cleft palate, congenital hypothyroidism, or isolated cleft palate," Thyroid, vol. 14, no. 8, pp. 584-588, 2004.

[22] A. Albrecht and S. Mundlos, "The other trinucleotide repeat: Polyalanine expansion disorders," Current Opinion in Genetics \& Development, vol. 15, no. 3, pp. 285-293, 2005.

[23] V. Camozzi, A. Tossi, E. Simoni, F. Pagani, C. M. Francucci, and L. Moro, "Role of biochemical markers of bone remodeling in clinical practice," Journal of Endocrinological Investigation, vol. 30, supplement 6, pp. 13-17, 2007.

[24] M. Polak, S. Sura-Trueba, A. Chauty, G. Szinnai, A. Carre, and M. Castanet, "Molecular mechanisms of thyroid dysgenesis," Hormone Research, vol. 62, no. 13, pp. 14-21, 2004.

[25] A. Carré, M. Castanet, and S. Sura-Trueba, "Polymorphic length of FOXE1 alanine stretch: Evidence for genetic susceptibility to thyroid dysgenesis," Human Genetics, vol. 122, no. 5, pp. 467476, 2007.

[26] R. Parlato, A. Rosica, A. Rodriguez-Mallon et al., "An integrated regulatory network controlling survival and migration in thyroid organogenesis," Developmental Biology, vol. 276, no. 2, pp. 464-475, 2004.

[27] J. S. Bamforth, I. A. Hughes, J. H. Lazarus, C. M. Weaver, and P. S. Harper, "Congenital hypothyroidism, spiky hair, and cleft palate," Journal of Medical Genetics, vol. 26, no. 1, pp. 49-51, 1989.

[28] M. Castanet, S.-M. Park, and A. Smith, "A novel loss-offunction mutation in TTF-2 is associated with congenital hypothyroidism, thyroid agenesis and cleft palate," Human Molecular Genetics, vol. 11, no. 17, pp. 2051-2059, 2002.

[29] I. Bariş, A. E. Arisoy, and A. Smith, "A novel missense mutation in human TTF-2 (FKHL15) gene associated with congenital hypothyroidism but not athyreosis," The Journal of Clinical Endocrinology \& Metabolism, vol. 91, no. 10, pp. 4183-4187, 2006.
[30] E. M. R. Rodrigues, T. de Jesus Brabo Ferreira Palha, and S. E. B. dos Santos, "Allele frequencies data and statistic parameters for 13 STR loci in a population of the Brazilian Amazon Region," Forensic Science International, vol. 168, no. 2-3, pp. 244-247, 2007.

[31] H. Lavoie, F. Debeane, Q.-D. Trinh et al., "Polymorphism, shared functions and convergent evolution of genes with sequences coding for polyalanine domains," Human Molecular Genetics, vol. 12, no. 22, pp. 2967-2979, 2003.

[32] M. Bullock, G. Lim, C. Li et al., "Thyroid transcription factor 1) interacts with ETS factor ELK1 to co-regulate TERT," Oncotarget, vol. 7, no. 52, pp. 85948-85962, 2016.

[33] A. Nikitski, V. Saenko, M. Shimamura et al., "Targeted foxel overexpression in mouse thyroid causes the development of multinodular goiter but does not promote carcinogenesis," Endocrinology, vol. 157, no. 5, pp. 2182-2195, 2016.

[34] E. Amendola, P. De Luca, P. E. Macchia et al., "A mouse model demonstrates a multigenic origin of congenital hypothyroidism," Endocrinology, vol. 146, no. 12, pp. 5038-5047, 2005. 


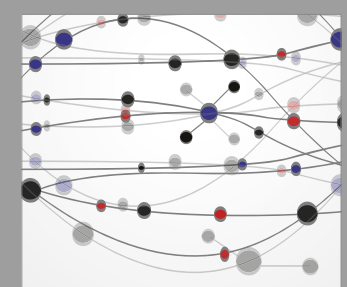

The Scientific World Journal
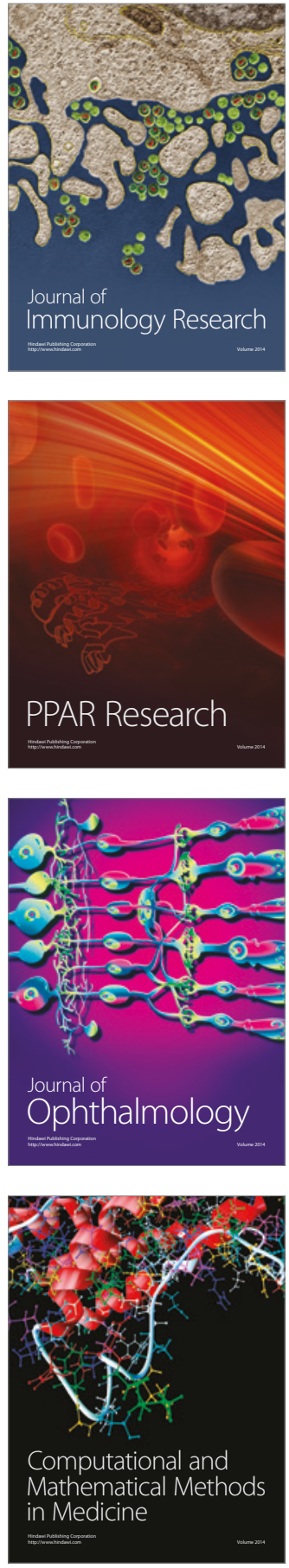

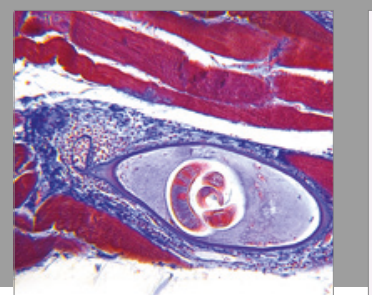

Gastroenterology Research and Practice
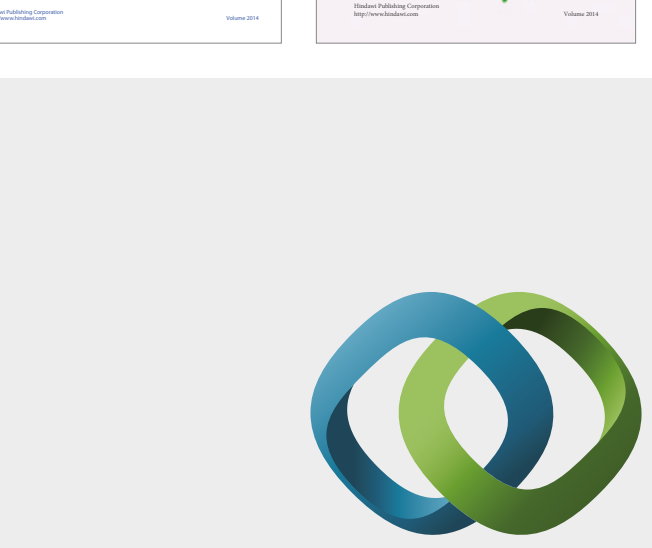

\section{Hindawi}

Submit your manuscripts at

https://www.hindawi.com
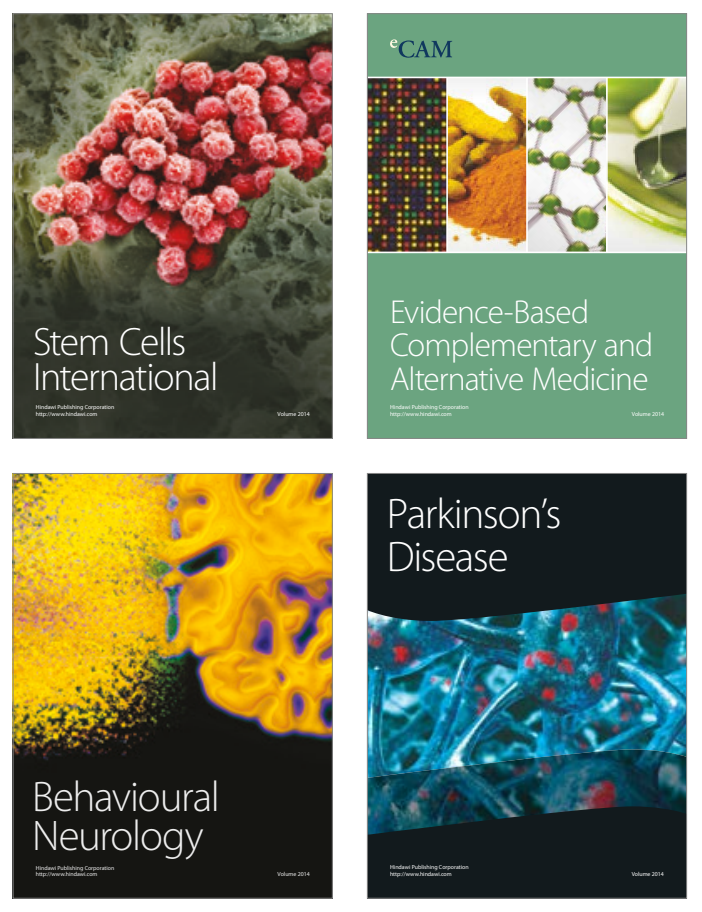
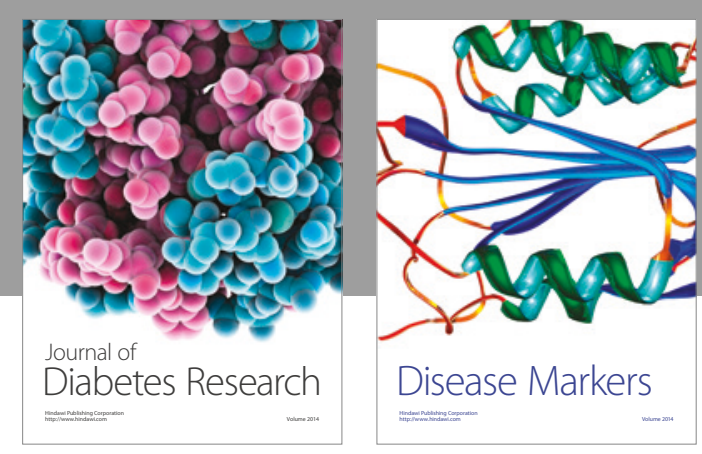

Disease Markers
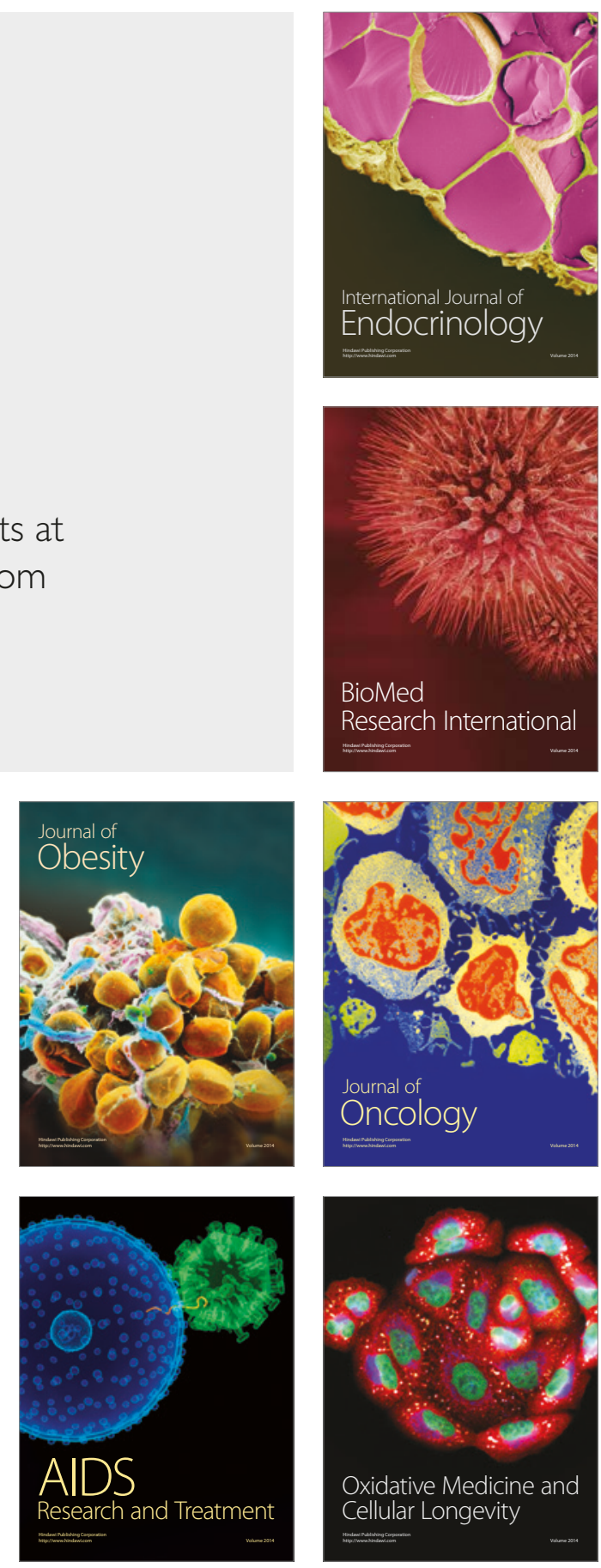